\title{
Gallimaufry
}

Ol: 10.1680/dare.2010 20.1 .1

\section{News and events from the British Dam Society}

Welcome to the first edition of Dams and Reservoirs of the new decade [Please don't write in and say the decade starts at the end of 2010 - you know what I mean! Ed.]. What the new decade holds for us all remains to be seen. For dams, however, the outlook appears to be one of change and (cautious) optimism with a likely resurgence of dam building worldwide. At the time of writing this, the Flood and Water Management Bill has had its second reading and is now in its committee stages. As a consequence legislative change in relation to reservoir safety is now firmly on the horizon.

The outlook at the start of this new decade looks more positive than at the start of the previous few decades. In the eighties and nineties dams fell from favour, particularly as vocal non-government organisations lobbied international funding agencies, with the rate of dam building falling by half between 1980 and 2000 .

Over the 'noughties' the rate of dam building climbed from about 200 a year in 2000 to a current rate of about 250 a year. Over the coming decade adaptation to climate change seems likely to drive further appropriate dam development in two areas: renewable energy in the form of hydropower and increased water storage to combat more extreme floods and droughts. In summary, the next decade should be an interesting time to be involved with dams. The theme of change is echoed in this year's British Dam Society (BDS) conference (see below).

I would like to take this opportunity to pass on our heartfelt thanks to Debbie Hay-Smith, outgoing editor of Dams and Reservoirs, for all her hard work over the last 3 years. The journal has seen significant changes in this time with the move to the new, improved format under the publisher Thomas Telford. I am just beginning to realise the effort that is put in by Debbie and the rest of the editorial panel!

As always the continued success of the journal relies on your willingness to write and submit interesting and informative articles and news. I would urge you make the effort to contribute. Please submit articles and news for consideration to: andrew.kirby@mottmac.com

\section{The BDS prize 2009}

Thanks to Tracey Williamson for providing this report on events at the BDS prize:

The final of the 2009 BDS prize competition was held at the Institution of Civil Engineers on Monday 23

November 2009. The competition, which is held every
2 years, is open to members of the BDS under the age of 35 .

From the 15 papers on dam engineering entered into the competition this year, four were selected for presentation at the final event. Following the presentation of their papers (detailed below), the finalists answered questions from the audience.

Paper 1: Marchlyn Mawr additional stored energy project by Giles Hird (MWH)

Paper 2: Research into the hydrodynamic forces and pressures acting within stepped masonry spillways by Clare Winter (MWH)

Paper 3: Remedial works at two Victorian embankment dams to allow safe passage of the probable maximum flood by Jonathan Walker (Mott MacDonald)

Paper 4: Design and construction of improvement works at Bruton flood storage reservoir, Somerset by Rachel Pether (Black \& Veatch)

The judges (Jonathan Hinks, Andrew Pepper and Tony Morison) scored the presentations and these were added to the scores awarded for the written papers. The judges' decisions were very close and they commended all the finalists for their excellent papers and presentations.

The cash prizes were given by Halcrow Group Ltd (as the employer of the outgoing BDS Chairman - Jonathan Hinks). In addition to a $\$ 300$ cash prize, the winner of the first prize - Giles Hird - also received an all-expensespaid trip to Malaysia to spend time at the construction site of the $62 \mathrm{~m}$ high Bengoh dam (sponsored by BDS). He will also attend the Hydropower and Dams Conference in Kuching on 29 and 30 March 2010 (sponsored by Hydropower and Dams).

The second prize of $₫ 300$ was awarded to Clare Winter, the third prize of $\$ 150$ went to Jonathan Walker and Rachel Pether received $\$ 75$ for fourth place.

The papers are all published in this issue of Dams and Reservoirs.

\section{Upcoming events}

A reminder, if any is needed, that the BDS's keynote conference is fast approaching. Our 16th British Dam Society Conference will be enjoying Scottish hospitality at the University of Strathclyde in Glasgow from 23 to 26
We welcome submissions from readers. Please send contributions (up to 250 words) to the Editor, e-mail: andrew.kirby@mottmac. $\mathrm{com}$ 
June. The theme of the biennial conference will be 'Managing Dams, the Challenges in a Time of Change'.

It is an excellent opportunity to meet old and new friends in the dams community from the UK and elsewhere. The conference includes interesting technical presentations, technical visits and the prestige Geoffrey Binnie lecture, being presented by John Cowie. In addition, there will be an exhibition area and a full accompanying persons programme in and around the Strathclyde area.

If you have not done so already, to register for the conference complete and return your registration form (available on the BDS website), with payment, not later than 19 April.

The 78th ICOLD annual meeting will be held in Hanoi, Vietnam from 23 to 26 May 2010. Visit www.icold-cigb. net/ for more information.

September seems to be conference season in Europe with the following events coming up:

The Second International Congress on Dam Maintenance and Rehabilitation will be held in Zaragoza, Spain on 28 to 30 September 2010. This is organised by the Spanish Society of Dams and Reservoirs (SEPREM) in collaboration with the Ministry of Environment. Visit www.

damrehabilitationcongress2010.com/en/index.htm for more information.

The 8th ICOLD European Club Symposium will take place from the 22 to the 23 of September 2010 in Innsbruck, Austria. The symposium's theme is Dam Safety - Sustainability in a Changing Environment. Visit www.icold-cigb.net/ for more information.

HYDRO 2010 will be held in Lisbon, Portugal between 27 and 29 September 2010. The conference has the theme Meeting Demands for a Changing World and is organised by the International Journal on Hydropower and Dams and edp. Visit www.hydropower-dams.com/ for more information.

\section{BDS website}

Keep up to date with upcoming meetings and events, issues and news on the BDS website www.britishdams. org. Past editions of Dams and Reservoirs are now freely available online. Since starting in 1967 the BDS journal has gone through three stages of evolution. Copies can be accessed via the BDS website at the links below:

BDS News \& Views (1967-1990)

BDS Dams \& Reservoirs (1991-2007)

BDS Dams \& Reservoirs (2008 onwards - current TTL publication)

In addition, discussion notes from past conferences (1986-2002) have also been uploaded.

\section{And finally...}

A note from Jonathan Hinks to encourage our involvement with colleagues worldwide in ICOLD:

The various committees are the backbone of ICOLD and have the very important task of preparing the influential technical bulletins. Native English speakers are always in great demand for drafting the bulletins and it can be very stimulating sitting on committees with the world experts on the various subjects.

The problem is finding the funding to travel to the annual meetings around the world but, if the money can be found, the meetings are stimulating and enjoyable.

Our present representatives are listed below but many of them would be willing to step down if presented with an interested and worthy successor. Those interested should speak, in the first instance, to the present incumbent or to Peter Mason, Andy Hughes or Jonathan Hinks.

\section{Stop press}

It is with great sadness that we announce the death of Professor Jack Lewin who passed away on the 6th of January. Jack was a leading authority on hydromechanical equipment and a long-standing member of BDS. An obituary will be published in the next edition of Dams and Reservoirs. 


\section{ICOLD committees}

\section{Committees}

Computational Aspects of Analysis and Design of Dams

Seismic Aspects of Dam Design

Hydraulics for Dams

Concrete for Dams

Materials for Fill Dams

Dam Surveillance

Environment

Dam Safety

Engineering Activities in the Planning Process for Water Resources Projects

Sedimentation of Reservoirs

Dam Decommissioning

Tailings Dams and Waste Lagoons

Operation, Maintenance and Rehabilitation of Dams

Public Awareness and Education

Register of Dams and Documentation

Constitutional Committee

Dams for Hydroelectric Energy

Small Dams

Dams and Floods

Dams and Water Transfers

Role of Dams in the Development and Management of River Basins

Cost Savings in Dam Construction

Groundwater Dams

Financial and Advisory Committee

Global Climate Change and Dams, Reservoirs and Associated Water

Resources
Chairman

UK representative

A. Carrere - France

Nil

M. Wieland - Switzerland Jonathan Hinks

A. Lejeune - Belgium Nil

R. Charlwood - USA Malcolm Dunstan

A. Marulanda - Colombia Rod Bridle

B. Goguel - France Jim Millmore

K. Baba - Japan Tracey Williamson

A. Zielinski - Canada Andy Hughes

A. Walz - USA Nil

G. Basson - South Africa Nil

E. D Edwards - USA Nil

R. Williamson - South Africa Mike Cambridge

P. Cummins - Australia John Gosden

P. Mulvilhill - USA Alison Bartle

W. Floegl - Austria lan Hope

F. Miguez - Brazil Andy Hughes

G. Ruggieri - Italy John Sawyer

F. Silveira - Brazil Andy Hughes

C. Guilaud - Canada Martin Airey

C. D. Thatte - India Nil

E. Cifres - Spain Nil

F. Lemperiere - France Peter Mason

H. S. Kim - Korea Nil

B. Tardieu - France Andy Hughes

R. Lemons - USA Martin Airey 